第 6 図 ステアルアミド，ステアロニトリル混合物の定量 (条件: $8 \mathrm{~N}-\mathrm{HCl}, 100^{\circ} \mathrm{C}, 4$ 時間)

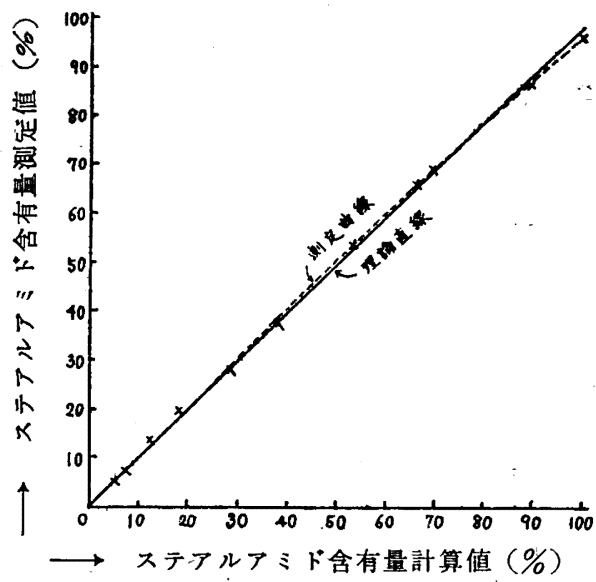

第 4 表 ステアルアミドの含有量大なる場合 (85\% 以上) の加水分解による定量

（条件： $8 \mathrm{~N}-\mathrm{HCl}, 100^{\circ} \mathrm{C}, 6$ 時間)

○ $⺀$ 含有量 $(\%)$

\begin{tabular}{|c|c|c|c|c|}
\hline 棓算値 & 測定値 & 差 & 差の平均值 & 平均俱差 \\
\hline 88.6 & 88.8 & +0.2 & \multirow{4}{*}{-0} & \multirow{4}{*}{0.4} \\
\hline 94.2 & 93.6 & -0.6 & & \\
\hline 94.5 & 94.2 & -0.3 & & \\
\hline 100.0 & $99 \sim 100.0$ & $-1.0 \sim 0.0$ & & \\
\hline
\end{tabular}

\section{IV. 実験結果の総括}

脂肪酸とアンモニアによるニトリルの直接合成法における反応 機構の究明のため，また工業化に際して，反応中間体の成分決定 のために, アミド, ニトリル混合物中のアミドの定量法を確立す る目的で加水分解速度を比較して，アミドが完全に加水分解し， ニトリルがほとんど分解しない条件を求め，これを分析に応用し ようとして種々実験を行い，次のような結果をえた。
1. アミドとニトリルの加水分解条件の比较について

ラウルアミドとラウロニトリル，およびステアルアミドとステ アロニトリルのいずれも加水分解速度に著しい羑があり，ラウル

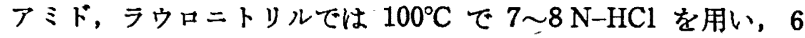
時間反応させると,アミドが完全に分解し、ニトリルはほとんど 分解せず， $120^{\circ} \mathrm{C}$ では 4 6 Nの $\mathrm{HCl}$ を用い， 6 時間反応させる と，やはりアミドが完全に分解し，ニトリルはほとんど分解しな い結果をえた。またステアルアミドとステアロニトリルでは 100 ${ }^{\circ} \mathrm{C}$ で 4 8 $\mathrm{N}$ の塩酸により 6 時間, $7 \sim 8 \mathrm{~N}$ の塩酸では 4 時間反 応させれば，アミドが完全に加水分解し，ニトリルはほとんど分 解しなかった。

\section{2. 分析方法の磪立について}

上記したアミドと，ニトリルの加水分解速度の差を利用して, それらの混合物よりアミドを定量する実験として，ラウルアミ ド，ラウロニトリルの混合物，ステアルアミド，ステアロニトリ ルの混合物について行い,アミド含有量が $85 \%$ 以下の場合は, 前 者のときは $7 \mathrm{~N}$ の塩酸, $100^{\circ} \mathrm{C}, 4$ 時間, 後者では $8 \mathrm{~N}$ の塩酸, $100^{\circ} \mathrm{C}$ ，4 時間反応すればよくまたアミドの含有量が $85 \%$ 以 上のときは，い与゙れも 6 時間反応させれば, 平均誤差 0.4 以下で 定量できる分析方法を確立しえた。この方法を利用して，直接二 トリル合成法の反応機構の探菜，ならびに工業化に際してうると ころが多かった。

\section{V. 結語}

高級脂肪族アミド，ニトリルの加水分解速度の差を利用して, ラウルアミド, ラウッニトリルの混合物, およびステアルアミド, ステアロニトリルの混合物中のアミドを，それぞれ定量しようと して, 前者では $7 \mathrm{~N}$ の塩酸により $100^{\circ} \mathrm{C} て ゙ 4$ 時間反応させ, 後 者では $8 \mathrm{~N}$ の塩酸で $100^{\circ} \mathrm{C} て ゙ 4$ 時間反応させることにより，混 合物中のアミドを定量することができた。

（昭和 29 年 4 月 2 日, 日化第 7 年会講演）

\title{
3ーケトブチル基または 3-オキシブチル基を有する分散モノア・染料†
}

（昭 和 31 年 1 月 10 日 受 理)

\section{黒木宣趁・丸山雄士・小西謙三*}

メチルビニルケトン（以下 MVK と略）はビニル基の隣りに 電子吸引性のカルボニル基を有するため, アクリルニトリルと同 様にアルコール類, アミン類等の活性水素化合物へ共役付加を行 いうる1)。われわれは $\mathrm{N}-$ エチルアニリンおよび N-(2-オキシエ チル) アニリンと MVK との反応によってそれぞれ N-エチルー

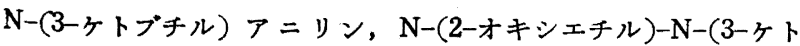
ブチル）アニリンを合成した。後者はまたアニリンと MVK との

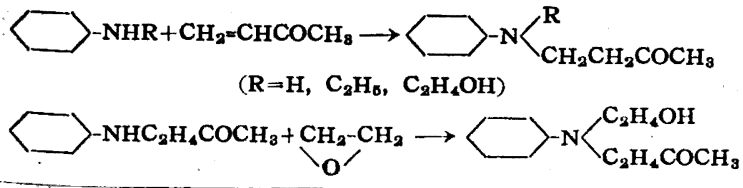

†本報を「合成辒維用染料に閣する研究（第 11 報)」とする.

* 大阪府立大学工学部応用化学教室：堺市百舌鳥.

1）村田, 新井, 工化 $56,628,709$ (1953); 57, 578 (1954).
反応でえた N-(3ーケトプチル) アニリンとエチレンオキシドと

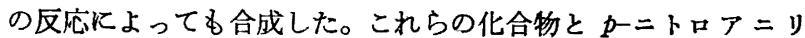

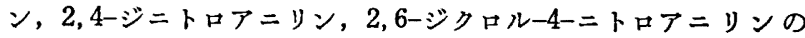
ジアゾ化物とを酸性でカップリングさせてモノアゾ化合物（I）, （II）をえた。

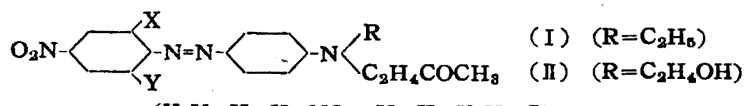
$\left(\mathrm{X}, \mathrm{Y}=\mathrm{H} ; \mathrm{X}=\mathrm{NO}_{2}, \mathrm{Y}=\mathrm{H} ; \mathrm{X}, \mathrm{Y}=\mathrm{Cl}\right)$

3ーケトブチル基はブチル基よりやや親水性が大きい程度である から, 前々報2) 拉よび前報3) の結果よりみて (I ) 型化合物はて セテート，ビニロン，アミランいずれに対しても染着性が低いこ とが予想される。しかし（II）のよ5に3-ケトブチル基ととるに

2) 黒木 5 , 工化 59, 619 (1956).

3) 埋木 5 , 工化 59, 626 (1956). 
2-オキシェチル基を有するものはセリトンスカーレットBに相当 するアท゙化合物 (III) と同程度, あるいはそれよりやや良好な程<smiles>CCN(CCO)C1CCCC(N=NN2CCC([N+](=O)[O-])CC2)CC1</smiles>

度の染着性を有するであろらと思われる。

実際にこれらのアゾ化合物を用いアセテート，ビニロン，アミ ランを分散染色した結果は上の予想のとおりであった。すなわら （I）型のあのはいずれもビニロンにあまり染着せず, アセテー ト，アミランも（III）より染着性が劣っていた。しかし既報2の シアノエチル基を有する染料よりは良好であった。ところがオキ シェチル体（II）はいずれす（III）と同程度の染着性を有してい た。これらの 3ーケトブチル基を有する染料のアセテート，ビニ ロンに対する鮮明度は良好であり，とくにアセテート上ではきわ めて鮮明である。アミラン上ではややくすんでいた。なお（I） 型化合物の洗たく堅审度は良好である。これらの化合物は既報2) にのベたシアノエチル基を有するアゾ化合物と同じく3ーケトブ チル基中のカルボニル基の電子吸引性のためにアルキル基あるい は 2-オキシアルキル基を有する対応アゾ化合物にくらべ浅色で あることが期待される。実際に可視部吸収スペクトルの測定結果 をみると（I），（II）型化合物の吸収はアルキル基またはオキシ アルキル基を有する化合物にくらべ短波長側に移動していること が示される。しかし 2-シアノェチル基を有する対応アゾ化合物 よりは長波長側に吸収を有しており, 後者と 2-オキシアルキル 体との中間の吸収を示している。

これらの (I), (II) 型染料（とくにI型）は3ーケトブチル基 が相当に疎水性であるために染着性が悪いのであるから,この基 中のカルボニル基をアルコール基に還元することによって親水性 を增大させれば染着性が向上すると思われる。故にわれわれはケ トブチル基を還元した型の染料, すなわち 3-オキシブチル基を 有する染料 (IV), (V) を合成し, そのアセテート,ビニロン, アミランに対する染着性を調べた。

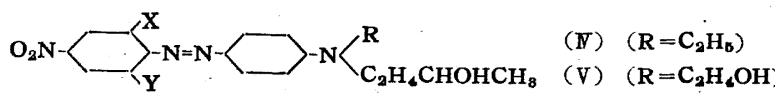$$
\left(\mathrm{X}, \mathrm{Y}=\mathrm{H} ; \mathrm{X}=\mathrm{NO}_{2}, \mathrm{Y}=\mathrm{H} ; \mathrm{X}, \mathrm{Y}=\mathrm{Cl}\right. \text { ) }
$$

この型の染料は N-(3-ケトブチル) アニリン類のラネーニッケ ルの存在下の接触水素還元によってえた N-(3-オキシブチル) ア ニリン類をカップリング成分として用い常法によりアジ化合物を 合成した。ただしオキシェチル化物は N-(3-オキシブチル) アニ

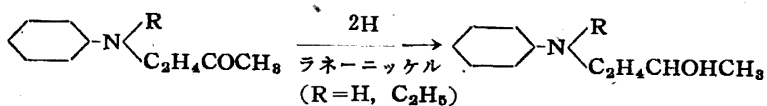

リンとエチレンオキシドとの反応で合成した。

これらのアゾ化合物は予期のとおり対応するケトブチル体より いずれも染着性が向上しており，(IV) 型化合物は 2-オキシプロ ピル体よりやや染着性が悪かった。このことはオキシプロピル基 はオキシブチル基よりやや親水性が大であるから, 当然予想され るところである。（V) 型化合物は親水性と疎水性とのバランス が最も適当であり, 対応 2-オキシプロピル体よりさらに染着性 は良好となって扣り，前報3)の N-エチル-N-(2,3-ジオキシプロ ピル）体と同程度にまで向上している。

鮮明度はケトブチル体よりは劣っていたが，(III）よりやや良 好であった。洗たく堅军度は水酸基を有するためヶトブチル り少っていた。
オキシブチル体の色調は電子吸引性のカルボニル基を有する対 応ケトブチル体と異なり, 電子供給性の水酸基を有するので後者 より深色となることが期待される。吸収スペクトルの測定結果は 予期のとおりであり, 前者の方が後者よりやや長波長側に吸収し ていた。

ケトブチル基を有するアท゙染料の中（I）型のるのは I. G. 社 のフランス特許4) 中に一, 二の例がアセテート用として記載され ているが（II）型のものはみられない。また，オキシブチル基 を有するアゾ染料は全く文献に見当らないようである。

\section{実 験 の 部}

\section{$\mathbf{N}$-(3-ケトブチル) アニリン類の合成}

N-(3-ケトブチル) アニリン, N-エチル-N-(3-ケトブチル) ア ニリン アニリンまたは N-ェチルアニリンを MVK とを村田, 新井の方法1)にしたがって, 常温で反応させて合成した。N-(3 ケトブチル) アニリンは $\mathrm{mp} 34.5 \sim 35.5^{\circ} \mathrm{C}, \mathrm{N} \% 8.50$ (計算值 8.58), セミカルバゾンの $\mathrm{mp} 166 \sim 167^{\circ} \mathrm{C}$ であった。 $\mathrm{N}-$ エチル $\mathrm{N}$-(3ーケトブチル)アニリンは bp $110 \sim 128^{\circ} \mathrm{C} / 3 \mathrm{mmHg}, \mathrm{N} \% 7.40$

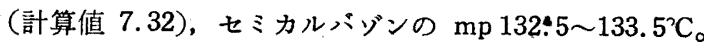

N-(2-オキシェチル)-N-(3-ケトフィル) アニリン N-(3-ケ トブチル）アニリン $16.3 \mathrm{~g}$, エチレンオキシド $4.4 \mathrm{~g}$ をナス型 フラスコに入れ, ゴムセンで密センをし, 初め室温 $\left(20 \sim 25^{\circ} \mathrm{C}\right)$ で放置する。約 2 時間後完全に均一な溶液となるから水浴上で $35^{\circ} \mathrm{C}$ で 42 時間反応させたのち減圧蒸留により bp 128 $135^{\circ} \mathrm{C} / 4$ $\mathrm{mmHg}$ の淡黄色の液体 $17 \mathrm{~g}$ をえた(理論の $82.5 \%$ )。 $\mathrm{N} \% 6.82$ (計算値 6.77)。

$\mathrm{N}$-(2-オキシェチル) ア゙ニリン $31.5 \mathrm{~g}$ に MVK $17.5 \mathrm{~g}$ を加 え, 1 時間かきまぜたのち 96 時間放置後水洗し, 無水ボウ硝上 で乾燥後減圧蒸留を行い，上記と同じ沸点の留分を集めた。収率 $50 \%$ 。本法では蒸留の際分解が多かった。

\section{N-(3-オキシブチル) アニリン類の合成}

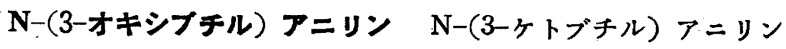
$10 \mathrm{~g}$ をメタノール $50 \mathrm{cc}$ に溶かし, ラネーニッケル合金 $2 \mathrm{~g}$ を 常法によって展開してこれに加え, 内容 $250 \mathrm{cc}$ のオートクレー ブに入れ, 水素初圧 $25 \mathrm{~atm}$ で $30 \sim 40^{\circ} \mathrm{C}$ で 1 時間反応させると 大体理論量の水素の吸収が終るから,さらに同温度で 1 時間ふり まぜたのち反応液をとり出し, ラネーニッケルをロ别し，メタ， 一ルを留去すると結晶を生じるので, 少量のメタノールから再絬 晶し, $\mathrm{mp} 56 \sim 58^{\circ} \mathrm{C}$ の白色結晶 $9.1 \mathrm{~g}$ (理論量の䄪 $90 \%$ ) をえ た。N\% 8.26 (計算值 8.48)。塩酸セミカルハシジドによってセミ カルバゾンは生成しなかった。

$\mathbf{N}-$ エチル-N-(3-オキシブチル) アニリンＮ-エチル-N-(3ケトブチル) アニリン $30 \mathrm{~g}$ にラネーニッケル合金 $3 \mathrm{~g}$ を常法に より展開したものを混合し, 内容 $250 \mathrm{cc}$ のオートクレーブに入 れ, 水素初圧 $30 \mathrm{~atm}$ で $30 \sim 32^{\circ} \mathrm{C}$ で 5 時間反応させたのち反応 液をとり出し，ラネーニッケルをロ別し，減圧蒸留を行い, bp $130 \sim 132^{\circ} \mathrm{C} / 5 \mathrm{mmHg}$ の留分 $21 \mathrm{~g}$ (理論の $70 \%$ )をえた。 $\mathrm{N} \%$ 7.41 (計算値 7.32)。塩酸セミカルバジドによってセミカルバฑ゙ ンは生成しなかった。

$\mathbf{N}$-(2-オキシェチル)-N-(3-オキシブチル) アニリン N-(3オキシブチル) アニリン゙ $16.5 \mathrm{~g}$ とエチレンオキシド $4.4 \mathrm{~g}$ をナ -4) I.G., F.P. 824,444 (1938). 
ス型フラスコに入れ，ゴムセンで密センして水浴上 $35^{\circ} \mathrm{C} て ゙ 20$ 時間反応させたのち，減圧蒸留により bp $210 \sim 240^{\circ} \mathrm{C} / 20 \mathrm{mmHg}$ の留分 $15.5 \mathrm{~g}$ (理論の $74.2 \%$ ) をえた。塩酸セミカルバジドに よってセミカルバン゙ンを生成しなかった。この淡黄色の粘い液体 をさらに減圧蒸留し $175 \sim 180^{\circ} \mathrm{C} / 14 \mathrm{mmHg}$ の留分を集めた。収 量 $10 \mathrm{~g}$ 。 $\%$ 6.56 (計算値 6.7)。

\section{3ーケトブチル巷または 3-オキシブチル基き有するモノアゾ染 料の合成}

それぞれ $\mathrm{N}-$ エチル-N-(3-ケトブチル)・アニリン, $\mathrm{N}-(2-$ オキ シェチル)-N-(3-ケトブチル) アニリン, $\mathrm{N}-$ エチル-N-(3-オキシ ブチル)アニリン， $\mathrm{N}-(2-$ (2キシエチル)-N-(3-オキシブチル)ア ニリンをカップリング成分に用い，そのメタノール水溶液にジア ゾ化した $p$ ーニトロアニリン, 2,4-ジニトロアニリン, 2,6-ジク ロルー4ーニトロアニリン水溶液を加え，アゾ化合物を合成した。 生成したアゾ化合物は酢酸ナトリウムでコンゴーレッド中性とし たのちロ過, 乾燥し, 適当な溶剤から再結晶した。合成した（I）， (II)，（IV)，（V）型アゾ化合物の収率および性質は第 1 表に示し た。表中の吸収極大值は $85 \%$ エタノールの $1 / 25000 \mathrm{~mol}$ 溶夜 に打梳六分光光電光度計 EPU-2 型による可視部吸収スペク トルの $\lambda_{\max }$ と $\varepsilon_{\max }$ を示した。他の表示は既報2)と同様である。

第1表 3-ケトブチル基または 3-オキシブチル基 を有するモノアゾ化合物

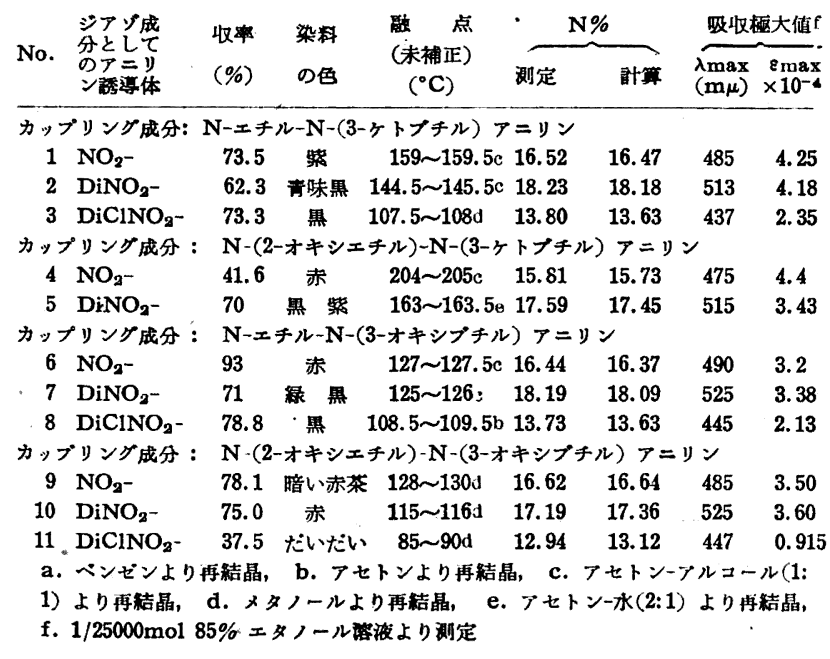

\section{吸収スペクトルの測定}

3ーケトブチル基または 3-オキシブチル基を有するモノア ゙゙化 合物の可視部吸収スペクトルはその $1 / 25000 \mathrm{~mol} 85 \%$ エタノー ル溶液を用い, 日立分光光電光度計 EPU-2 型で测定した。測㝗 絬果は第 1〜3 図に示すとおりである。これらの曲線からカップ リング成分が同一の場合はジクロルニトロ，ニトロ，ジニトロ体 の順に色が梁くなることは前報3，前々報2)の結果と同様である ことがわかる。 $\lambda_{\max }$ をみるとニトロ体はジクロルニトロ体より 38〜 48 m $\mu$, ジニトロ体はニトロ体より $28 \sim 40 \mathrm{~m} \mu$ だけ長波長側 に吸収極大値を有することが示される。

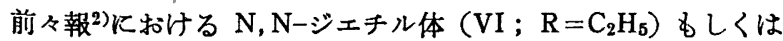
$\mathrm{N}$-エチル-N-(2-オキシェチル) 体 (VI; $\left.\mathrm{R}=\mathrm{C}_{2} \mathrm{H}_{4} \mathrm{OH}\right)$ の $\lambda_{\max }$ と $\mathrm{N}$-エチル-N-(3-ケトブチル) 体 (VI ; $\left.\mathrm{R}=\mathrm{C}_{2} \mathrm{H}_{4} \mathrm{COCH}_{3}\right)$ の $\lambda_{\max }$ とを比較すると前二者にくらべ後者はニトロ体で 5〜10 $\mathrm{m} \mu$, ジニトロ体は $12 \sim 17 \mathrm{~m} \mu$ ， ジクロルニトロ体は $13 \mathrm{~m} \mu$ だ け浅色であることがわかる(第 2表)。これはケトブチル基中の
第 2 表 (VI) 型 化 合物 の $\lambda_{\max }$

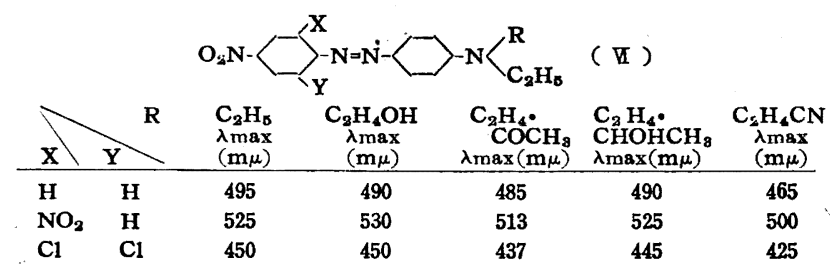

カルボニル基の電子吸引性によってケトブチル基全体の電子供給 性がェチル基, オキシェチル基より小となっているためであろ 5。しかし, ケトブチル基の電子吸引性は 2-シアノェチル基よ りは大分弱い。第.2表より対応 2-シアノェチル体と 3-ヶトブチ ル体との $\lambda_{\max }$ をくらべるとニトロ体は 20 ，ジニトロ体は 13 , ジクロルニトロ体は $13 \mathrm{~m} \mu$ だけ後者の方が梁色であることがわ かる。すなわち 3ーケトブチル基は 2-オキシェチル基と 2-シア ノェチル基の中間程度の電子供給性である。3-オキシブチル体 (VI； $\mathrm{R}=\mathrm{C}_{2} \mathrm{H}_{4} \mathrm{CHOHCH}_{3}$ ) の $\lambda_{\max }$ と対応ヶトブチル体の $\lambda_{\max }$ 第 1 図 第 1 表中のアゾ化合物の吸収スペクトル

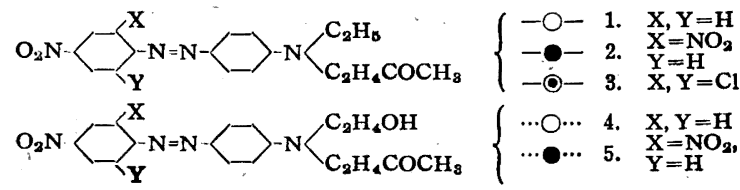

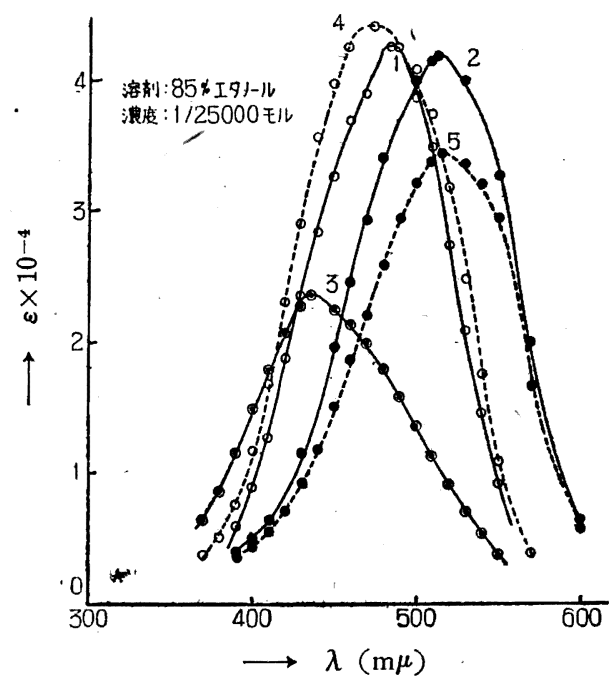

第 2 図第 1 表中のアゾ化合物の吸収スペクトル

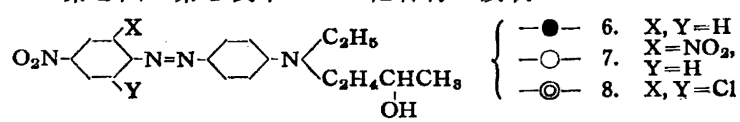

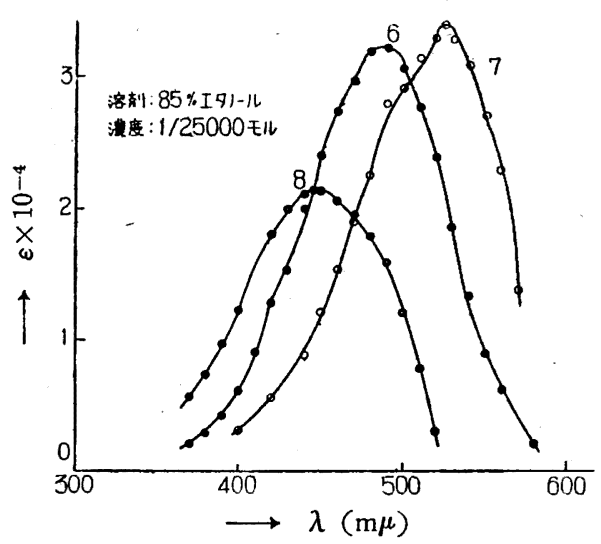


第 3 図 第 1 表中のアジ化合物の吸収スペクトル

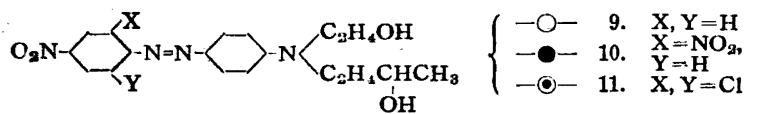

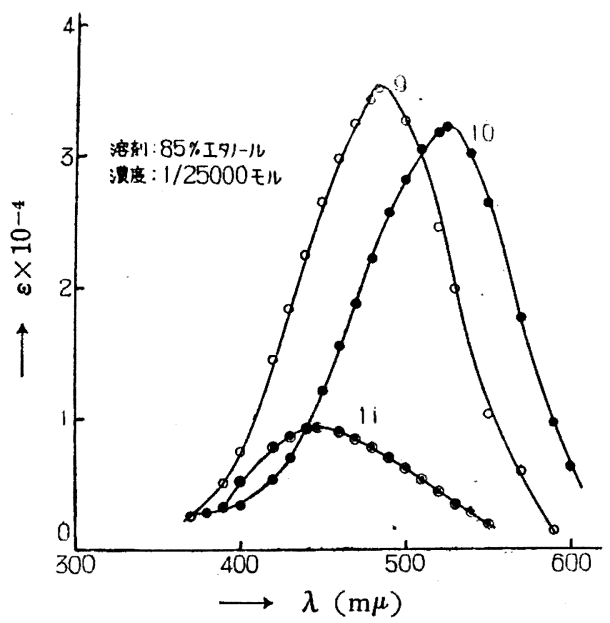

とをくらべるとニトロ体で 5 , ジニトロ体で 12, ジクロルニト 口体で $8 \mathrm{~m} \mu$ だけ長汥長側に吸收が移動している。これは電子 吸引性のカルボニル基が電子供粭性の水酸基に変換された絬果で ある。

\section{染色および結果}

前々報2)におけるアセテート，ビニロン，アミランと同一の布 を用い同一の条件(浴比 $20: 1,80^{\circ} \mathrm{C}, 1 \mathrm{hr}$, 染料は布の $2 \mathrm{wt} \%$ ) で染色した。ただし No. 1〜3 のみはアセテートは 100\% つや けしアセテート綾織布を用いた。染色結果は第 3,4 表に示した。

第3 表 3-ケトブチル基または 3-オキシブチル基を 有するアゾ染料による染色結果

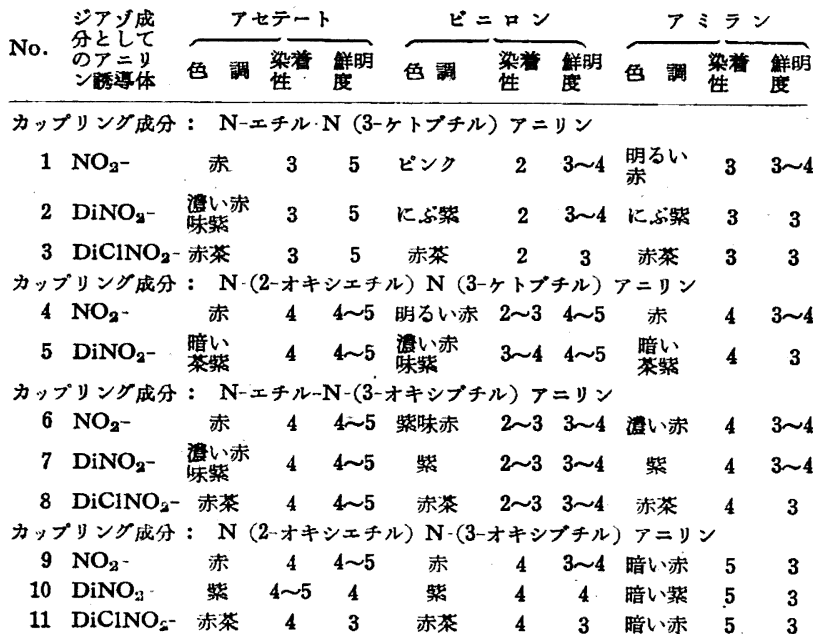

色調, 染着性, 鮮明度の測定は前々報 ${ }^{2)}$ と同様であり, 七リト ンスカーレットB相当物（III）でアセテートを $2 \%$ 染めしたもの を標準とした。

第 3 表から 3ーケトブチル基はあまり染着性に良好な結果を与 えないが，2-シアノエチル基よりはまだ良好であることがわか る。しかし，エチル基のかわりに2-オキシェチル基を有する (II) は相当に染着性は向上し，(III）と同程度の染着性である。（I） のケトブチル基を還元して 3-オキシブチル基にかえた（IV）は
（I）より染着性は增大しているが（II）よりはやや少ってい る。ところが, オキシェチル基とオキシブチル基を有する（V) は染着性が良好であり,ビニロンもアセテートと同程度に染着す る。一般にはアセテート,アミラン,ビニロンの順に染着性はお ちている。

3ーケトブチル基を有する染料は一般にアセテート上できわめて 鮮明である。アセテート上にくらベビニロン，アミラン上ではや やくすみがある。とくにアミラン上ではくすみが多かった。3ーオ キシブチル基を有する染料のらち（IV）は一般に鮮明であった が，オキシェチル体 (V) はややくすみが多かった。

第 4 表 3ーケトブチル基または 3-オキシブチル基を 有するモノアゾ染料の堅审度試験結果

\begin{tabular}{|c|c|c|c|c|c|c|c|c|c|}
\hline \multirow{2}{*}{$\begin{array}{l}\text { 染 } \\
\text { 慗 } \\
\text { 舟 }\end{array}$} & \multicolumn{3}{|c|}{ アセテート } & \multicolumn{3}{|c|}{ 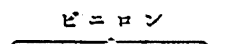 } & \multicolumn{3}{|c|}{ アミラン } \\
\hline & 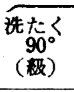 & (級) & $\begin{array}{l}\text { 日光 } \\
\text { (辍) }\end{array}$ & $\begin{array}{c}\text { 洗たく } \\
90^{\circ} \\
(\text { 粐) }\end{array}$ & 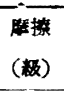 & $\begin{array}{l}\text { 日光 } \\
\text { (磉) }\end{array}$ & $\begin{array}{c}\text { 珗たく } \\
90^{\circ} \\
(\text { 极) }\end{array}$ & 暨撔 & $\begin{array}{l}\text { 日光 } \\
\text { (緅) }\end{array}$ \\
\hline 1 & 4 & 5 & 4 & 4 & 3 & $3 \sim 4$ & 3 & 3 & 2 \\
\hline 2 & 4 & 5 & 3 & 4 & 5 & 3 & $3 \sim 4$ & $3 \sim 4$ & 2 \\
\hline 3 & 4 & 5 & 4 & 4 & 4 & 4 & $2 \sim 3$ & $2 \sim 3$ & 2 \\
\hline 4 & 3 & 3 & 5 & 3 & $2 \sim 3$ & $4 \sim 5$ & 3 & $2 \sim 3$ & 4 \\
\hline 5 & 3 & 5 & 3 & $2 \sim 3$ & 4 & 2 & 3 & $4 \sim 5$ & 2 \\
\hline 6 & 3 & $2 \sim 3$ & 6 & 3 & $2 \sim 3$ & 6 & 3 & $2 \sim 3$ & 4 \\
\hline 7 & 3 & 3 & 3 & $2 \sim 3$ & $2 \sim 3$ & 2 & $2 \sim 3$ & $2 \sim 3$ & 2 \\
\hline 8 & 4 & 4 & $5 \sim 6$ & 2 & 4 & 4 & 3 & $2 \sim 3$ & $4 \sim 5$ \\
\hline 9 & 3 & 5 & 5 & $2 \sim 3$ & 4 & $4 \sim 5$ & $2 \sim 3$ & 5 & 4 \\
\hline 10 & 3 & 5 & 3 & $2 \sim 3$ & $4 \sim 5$ & 2 & $2 \sim 3$ & 5 & 2 \\
\hline 11 & 3 & 5 & 6 & 2 & 5 & 4 & 2 & 5 & 5 \\
\hline
\end{tabular}

堅牢度の表示は前報3) と同じである。日光堅牢度は青色標準布 を用い, 東洋理化フェードテスターで試験した結果である。

ケトブチル基を有する（I）型染料は洗たくに堅军であるが, 水酸基を有する（II)，(IV)，(V) 型染料はいずれるケトブチル 体より洗たく堅牢性が劣っていた。日光堅牢度は後者の方がすぐ れており,とくにアミランはケトブチル体より大分堅审となった。

\section{䋓括}

1. $\mathrm{N}$-エチルアニリン, $\mathrm{N}-(2$-オキシェチル $)$ アニリンと $\mathrm{M}$ VK との反応でえた $\mathrm{N}-$ チル-N-(3-ケトブチル) アニリン， $\mathrm{N}-(2$-オキシェチル)-N-(3-ケトブチル) アニリンをカップリン グ成分とし，p-ニロアニリン類をジアゾ成分とするモノアゾ化 合物 (I， II) を合成した。

2. ラネーニッケルを触媒とする接触還元によってNー(3ーケト ブチル) アニリン, N-エチル-N-(3-ケトブチル) アニリンより 対応 3ーオキシブチルアニリンを合成した。また N-(3ーオキシブ チル) アニリンとエチレンオキシドとの反応によってN-(2-オキ シェチル)-N-(3ーオキシブチル) アニリンを合成した。

この $\mathrm{N}$-エチル体， $\mathrm{N}-(2$-オキシェチル) 体をカップリング成

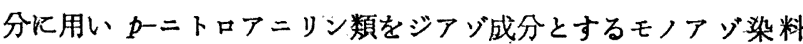
（IV，V）を合成した。

3. これらのモノアゾ化合物の融点, 吸収スペクトル值および アセテートビニロン,アミランに対する染着性をしらべた。

4. ケトブチル体 (I）の染着性はあまり良好でなかったが, オキシェチル基をいっしょに有するケトブチル体（II）は大分染 着性が向上する。またケトブチル基を還元したオキシブチル体 （IV，V） も相当染着性は向上した。とくに（V) の染着性は相 当代良好であり，ビニロンもアセテートと同程度に染まった。

（本研究の一部は Bulletin of Naniwa University Series 
$A^{5}$ に発表したし，また一部は有機合成特別研究発表会（昭和 29 年: 11 月, 東京) および有機合成化学講演会（昭和 30 年 6 月, 大阪）で発表した)。

5) 黒木, 小西 Bulletin Naniwa University Series A 2, 135 (1954).
本研究費の一部は文部省科学試験研究費によった。また用いた

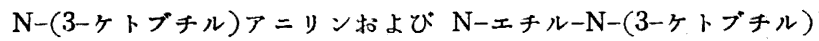
アニリンの一部は本学新井秀男氏にいただた。，日光堅审度試験 はすべて大東化学工業所でしていたたいた。ここにあわせて感謝 の意を表する。

\section{フェニルモルホリン環を有する分散モノアソ染料†}

(昭 和 31 年 1 月 10 日受理)

\section{黒木 宣西 野}

$\mathrm{N}, \mathrm{N}$-ビス (2-オキシェチル) アニリンの分子内脱水で生成す る 4-フェニルモルホリンをカップリング成分とするアり゙染料は オキシアルキル基を有するアジ化合物にくらべてはるかに眯水性 であると考えられる。したがって前報までの結果1よりみてこ れらの染料のアセテート, ビニロン, アミランに対する染着性は 相当に低いであろろと思われる。しかし一方, モルホリン誘導体 は有機溶剤としてきわめて溶解力が大きいことが知られており， 有機溶剈にほとんど溶解しない硫化染料でさえ溶解する2) 点より みると，アセテート，ビニロン，アミランに対する染着力が大き いのではないかとも考光られる。

この点を確かめるため, われわれはまずフェニルモルホリン誘 道体として 4-フェニルモルホリン, 2-メチルー4-フェニルモルホ リン, 2,6-ジメチル-4-フェニルモルホリンの3 種を合成し, こ れらをカップリング成分とするモノアッ゙染料 (I ), (II), (III) を合成した。

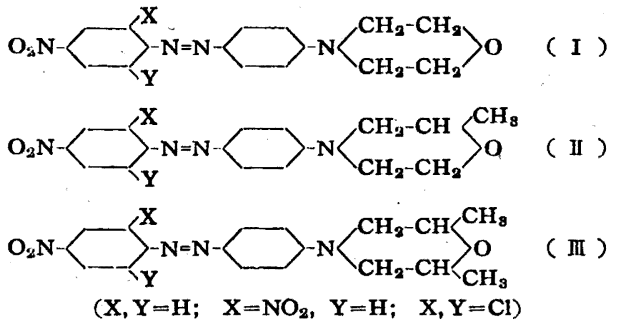

これらの染料はいずれすあまり染着性は良好でなく，とくにビ ニロン, アミランの染着性は悪かった。アセテートは前二者より はやや染まりが良かった。一般に鮮明度もセリトンスカーレット B相当化合物にくらべやや劣っており，その中でもアミランが最 もくすんでいた。

これらの結果から前報までの結論1) と同様に,アセテート,ビ ニロン, アミランのよ5.な疎水性の紻維用の染料においてるあま りにも蹯水性では染着性が悪く，モルホリン環程度の親水性では あまり染着性は良好でないことが示された。

そこでわれわれはさらにフェニルモルホリン環を有するアン゙染 料においてるある程度の親水性基を有する時は, アセテート等へ の染着性が向上することを確かめるために，2-クロルメチルー, 2-アセトキシメチルー拈よ゙ 2-オキシメチルー4-フェニルモルホ

†本報を「合成織維用染料に関する研究（第 12 報)」とする.

* 大阪府立大学工学部応用化学教室: 堺市百舌鳥.

1) 黒木 5, 工化 59,619,626, 905 (1956).

2) K. Venkataraman, et al, Proc. Indiana Acad. Sci. 28, 111 (1948).
リンよりのモノアゾ染料（IV)，（V)，（VI）を合成し, その染着 性を調べた。

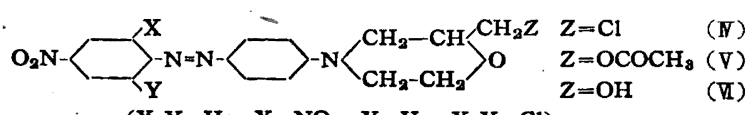

$\left(\mathrm{X}, \mathrm{Y}=\mathrm{H} ; \quad \mathrm{X}=\mathrm{NO}_{2}, \mathrm{Y}=\mathrm{H} ; \quad \mathrm{X}, \mathrm{Y}=\mathrm{Cl}\right)$

このうちクロルメチルモルホリン体（IV) は（I～III）よりや や親水性、アセトキシメチル体 (V), オキシメチル体 (VI) は （IV）よりいっそ5親水性であり，合成瀻維用として適当な親水 性を有することが想像される。染色結果はこの予想の正しいこそ を示している。すなわち（IV）は（I）より僅かに良好な染着性 を示したが（V）および（V）はビニロンに対してセリトンスカ ーレットB相当化合物以上の染着性を示した。アセテート，アミ ランに対する染着性も（I～III）より向上しているが，七リトン スカーレットB相当化合物よりはやや悪かった。鮮明度も（V), （VI）型化合物は（I～III） 型化合物よりやや向上している。

フェニルモルホリン類の合成はそれぞれ $\mathrm{N}, \mathrm{N}$-ビス (2-オキシ エチル) アニリン, N-(2-オキシプロピル)-N-(2-オキシェチル)

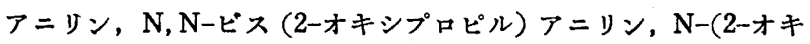
シェチル)-N-(2-オキシー3-クロルプロピル) アニリンンの濃硫酸脱 水によって合成した。

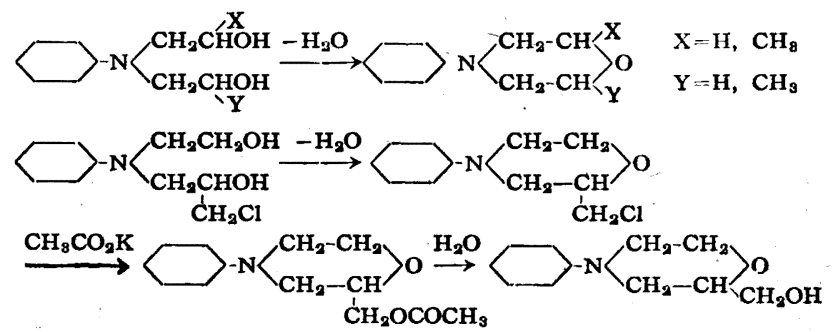

2-アセトキシメチル-4-フェニルモルホリンは 2-クロルメチ ルー4ーフェニルモルホリンのジメチルホルムアミド溶液に酢酸カ リウムを加え, ヨウ化カリウムの存在下に反応させて合成した。 オキシメチル体はアセトキシメチル体の加水分解によって合成し た。

フェニルモルホリン環を有するモノアジ化合物の色調は開環し ていないジアルキルアミノアニリンよりのアジ化合物にくらべ大 分浅色であり，その吸収強度も今までのモノアジ化合物にくらべ やや低い場合が多い。

本報告に批けつェニルモルホリン誘導体は 4-フェニルモル ホリン以外はいずれる文献にみられない。(I)〜（VI）型モノア ゾ化合物もいずれる文献に記載がない上5である。しかし 4-フ エニルモルホリンをカップリング成分とし 2,4-ジアシルアニリ 